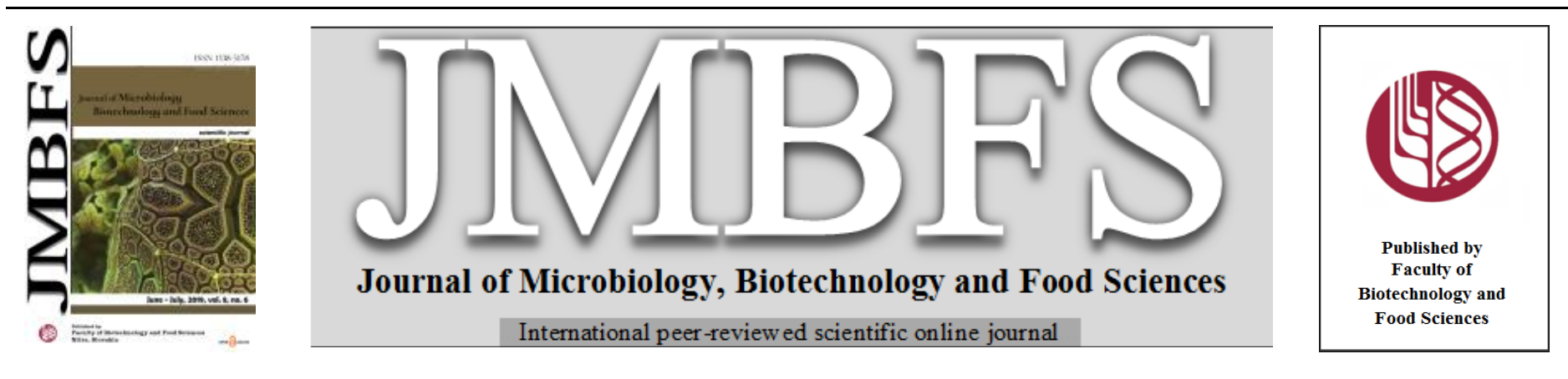

\title{
MYCOPLASMOSIS IN POULTRY, A PERPETUAL PROBLEM
}

\author{
Muhammad Shoaib* \\ Address(es): Muhammad Shoaib, \\ Department of Microbiology, Faculty of Biology, Baku State University, Azerbaijan.
}

*Corresponding author: shoaib1676@gmail.com

doi: $10.15414 / j m b f s .2019 .8 .6 .1271-1275$

\section{ARTICLE INFO}

Received 10.11.2018

Revised 31. 1. 2019

Accepted 4. 2. 2019

Published 1. 6. 2019

Review

open $\odot$ access

\begin{abstract}
Bacterial diseases are a huge concern for poultry farmers and cause huge economic losses to poultry industry every year. Various diseases can initiate respiratory signs in poultry, including mycoplasmosis. Mycoplasmosis is a major threat currently faced by poultry industry worldwide. In poultry main pathogenic species of Mycoplasma are Mycoplasma gallisepticum and Mycoplasma synoviae. Mycoplasma is a worldwide avian pathogen that causes immense losses in the poultry industry by decreasing eggs production, reducing growth and increased condemnation at slaughter houses. Mycoplasma is a wall-less bacterium that causes chronic respiratory disease in all types of chickens. Mycoplasmosis is an egg transmitted, hatchery disseminated and economically very important disease of chickens. Commonly used methods for diagnosis of Mycoplasma include isolation and identification of bacteria, several serological tests and molecular techniques. Closely located poultry farms, rearing of mixed avian species in close milieus, mixed commercial poultry farming and presence of wild birds in close proximity to poultry farms have made this disease very difficult to control. The review summarized the pathogenesis of Mycoplasma, associated risk factors, diagnostic tools and control measures. Best measures to control Mycoplasmosis include biosecurity, hygiene, good management, monitoring and removal of infected flocks, routine vaccination and farmer awareness. To reduce the risk of transmission of disease to other poultry populations, there should be continued monitoring of flocks for Mycoplasma.
\end{abstract}

Keywords: Mycoplasma, poultry, prevalence, economic losses, diagnosis, control

\section{INTRODUCTION}

Poultry industry alleviates the poverty by offering enormous opportunities to millions of people in the country. Availability of poultry meat is $3.90 \mathrm{Kg}$ per capita in Pakistan, $55 \mathrm{Kg}$ per capita in Kuwait, $50 \mathrm{Kg}$ per capita in USA and 12 $\mathrm{Kg}$ per capita in the world per annum. This condition is similar regarding the consumption of eggs. There is a big gap in the consumption of the poultry meat and eggs. This is due to many problems which are being faced by the poultry industry of Pakistan. One of the major problems is economic losses caused by infectious diseases. The main threats are the diseases caused by Mycoplasma species (Marois et al., 2001). The main pathogenic species of Mycoplasma are Mycoplasma gallisepticum (M. gallisepticum) and Mycoplasma synoviae (M. synoviae) (Umar et al., 2017). Mycoplasma causes immense losses in the poultry industry by decreasing eggs production, reducing growth and increasing condemnation at slaughter house (Kleven, 2008; Ferguson-Noel and Williams, 2015). About $10-20 \%$ losses in eggs production has been reported in the flocks affected from Mycoplasmosis (Bradbury and Morrow, 2008). Mycoplasmas are free living and self-replicating bacteria which are known to have the smallest genome and have low G+C content about 23-40\%. (Nicholas and Ayling, 2003). Cell wall is absent in Mycoplasmas. The cell membrane of these organisms is incorporated with sterols which differentiates them from other organisms (Kleven, 2008). Based on 16S rRNA analysis Mycoplasma belongs to phylum Firmicutes, class Mollicutes and family Mycoplasmataceae (Ley, 2003; Ley, 2008). In birds out of 22 known species of Mycoplasma, the four common pathogenic species include $M$. gallisepticum, $M$. synoviae, $M$. meleagridis and $M$. iowae (Bradbury, 2001). Of all avian Mycoplasma pathogens, $M$. gallisepticum and $M$. synoviae are important species due to high prevalence in different types of poultry and $M$. gallisepticum is being considered the most pathogenic (Umar et al., 2017). Other than chicken turkeys, quails, partridges, pheasants and pigeons are also the natural hosts of $M$. gallisepticum (Ley, 2003). M. gallisepticum causes chronic infections in both chickens and turkeys and is the most virulent of all the Mycoplasma species (Liu et al., 2001). M. gallisepticum and M. synoviae cause respiratory disease in both chickens and turkeys while $M$. iowae and $M$. meleagridis cause diseases only in poultry (Fan et al., 2011).
M. gallisepticum causes chronic respiratory disease (CRD) in the chickens and its incubation period is 16-21 days (Siddique et al., 2012). Gasping, respiratory rales, coughing, nasal discharge and rhinitis are the major signs of CRD Sometimes $M$. gallisepticum causes arthritis, salpingitis, conjunctivitis and fatal encephalopathy (Much et $\boldsymbol{a l}$., 2002). In the egg type birds, it causes marked decrease in eggs production and embryo mortality (Mukhtar et al., 2012). M. synoviae is very important poultry pathogen worldwide with respect to the economic losses caused by it such as decreased eggs production, growth retardation and condemnation of poultry meat at slaughterhouse. It usually causes infectious synovitis (respiratory infection) in chickens and may result in sub clinical infection. At present, $M$. synoviae causes infectious synovitis less frequently and air sacculitis more frequently in chickens and turkeys (Benčina $\boldsymbol{e t}$ al. 2001; Jacob et al., 2014). It causes air sacculitis which can also be the result of co-infection with $M$. gallisepticum and E. coli. When infection becomes systemic, it causes inflammation of synovial membranes of joints and tendon sheaths causing synovitis, tenovaginitis and bursitis (Kleven, 2008).

\section{CHRONIC RESPIRATORY DISEASE (CRD)}

M. gallisepticum and M. synoviae both cause CRD in all types of chickens (Bradbury and Morrow, 2008). The primary causative agent of CRD is $M$. gallisepticum and it causes disease under stress and poor management conditions or when a bird is suffering from some other respiratory problem (Papazisi et al., 2002). In the expanding poultry industry, $M$. gallisepticum is the most virulent avian pathogen and causes worldwide outbreaks leading to immense economic losses (Evans et al., 2005). It primarily damages respiratory tract by colonizing it and then secondary bacteria like E.coli and viruses invade there and cause severe infections (Liu et al., 2001; Peebles et al., 2015). Extensive antibiotic treatment is used to keep Mycoplasma under check and attenuated vaccines are used to prevent the disease but complete eradication of pathogen is very difficult. $M$. gallisepticum is the only avian Mycoplasma specie which is invasive in vitro as well. This is the reason it not only resists host defense and antibiotics but also enters the blood and causes systemic infection (Winner $\boldsymbol{e t}$ al., 2000; Umar et al., 2017 ). 
M. gallisepticum causes disease in birds of all ages but immunocompromised birds are more susceptible to this pathogen (Nunoya et al., 1995). In case of infection, the organism first colonizes the respiratory tract and in different strains of $M$. gallisepticum the tissue tropism, cell injury, attachment and pathogenicity varies (Sun et al., 2017). It is vertically transmitted through eggs and disseminated in hatchery. Decreased hatchability and low eggs production coun for the major economic losses caused by M.gallisepticum. Infected birds produce low quality day old chicks and slower growth rate. This also leads to increased medication and control procedure costs in the farming (Ley, 2003). The pathogenesis of Mycoplasmas in poultry is summarized in Figure 1 and 2.

Sialoglycoprotein receptors in the respiratory epithelium are required for the attachment of the Mycoplasma to the epithelial cells and initiation of the disease The process is mediated through cyto-adherence. To escape the innate host defense, attachment is very important process. Since many metabolic pathways are absent in the Mycoplasma, so for their survival it needs very close interaction with the host cell (Simecka et al., 1992). Mycoplasma species have the ability to cause direct cell injury, although exact mechanism of cell injury is not being understood. Mycoplasmosis causes cell injury by depriving nutrients, producing toxic substances and alteration in the host cell metabolites. Mycoplasma species produce enzymes like phospholipases, proteases and nucleases. These enzymes cause membrane damage to host cell and increase the chances of genetic alteration in host cell which may lead to auto immune disease (Bhandari and Asnani, 1989; Umar et al., 2017). Mycoplasma species produce hydrogen peroxide which play very important role in cell injury as well as damage to cell membrane and facilitates the entry of Mycoplasma during adherence process. As shown in figure 2 that hydrogen peroxide released by Mycoplasma causes oxidative stress to host cell and may also cause hemolysis. Nascent oxygen $\left(\mathrm{O}_{2}^{-}\right)$ is produced from hydrogen peroxide by catalase enzyme. This nascent oxygen $\left(\mathrm{O}_{2}^{-}\right)$causes oxidative damage inside the host cell and responsible for major cell injury. To counter this oxidative damage antioxidant enzymes like glutathione (GSH) and superoxide dismutase (SOD) are produced by the host cell. In this way host cell directs its energy for producing these enzymes to encounter oxidative damage caused by Mycoplasma (Razin et al., 1998; Razin, 2006; Xu et al., 2015).
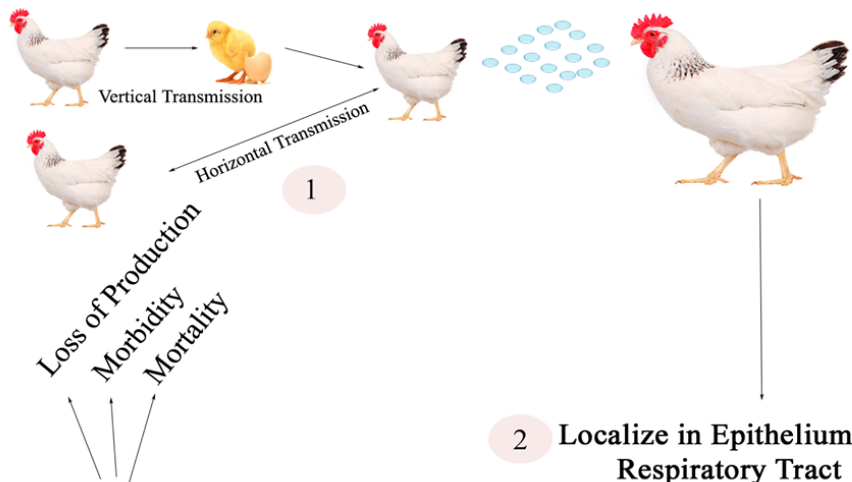

2 Localize in Epithelium of Respiratory Tract

Clinical Signs/Lesions

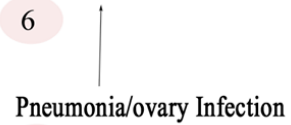

5

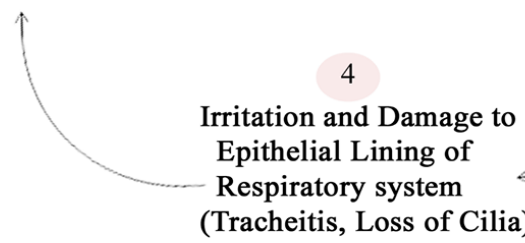

Figure 1 Pathogenesis of Mycoplasma gallisepticum

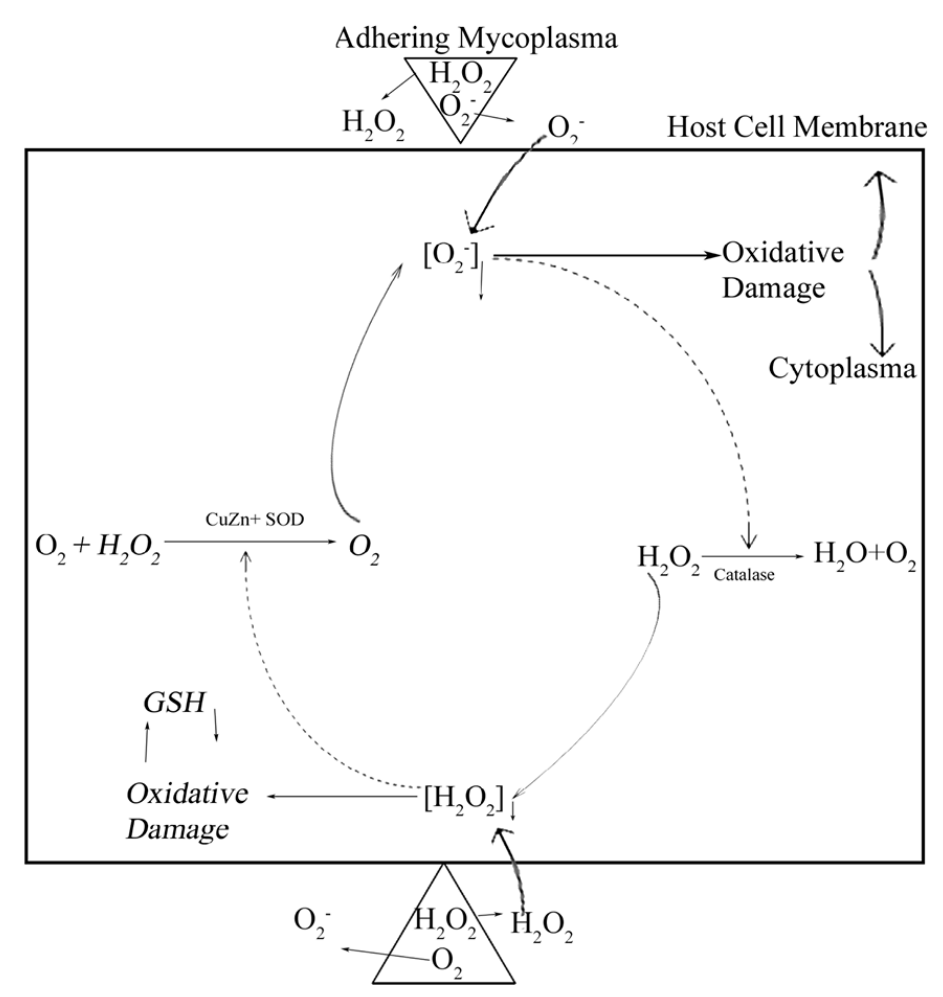

Figure 2 Sequence of events for oxidative damage in host cell caused by Mycoplasma (Razin, 2006)

Mycoplasma is transmitted vertically through eggs and horizontally through close contact, air borne droplets and contaminated dust particles (Papazisi et al., 2002; Umar et al., 2017). Increased population of poultry in an area due to rapid expansion increases the risk of transmission of Mycoplasma. It is one of the reasons why it is difficult to maintain Mycoplasma free flocks (Lysnyansky et al,. 2005).

The clinical signs in the birds infected with $M$. gallisepticum include open mouth breathing, rales and respiratory sounds. Nasal discharge, coughing and sometimes conjunctivitis are also seen in the infected birds (Saif $\boldsymbol{e t}$ al., 2003). Lacrimation and depression is also observed in infected birds (Forrester et al., 2011) Sometimes fatal encephalopathy, arthritis and salpangitis are seen in $M$ gallisepticum infected birds (Much et al., 2002).In the case of infected broiler breeder and commercial layer, sharp decrease in eggs production takes place. There is marked increase in embryo mortality in eggs of infected birds (Ley, 2003). The clinical signs in $M$. synoviae infection are somewhat similar to $M$. gallisepticum. M. synoviae causes subclinical upper respiratory tract infection and synovitis in chickens and turkeys is one of very important clinical findings $M$. synoviae causes air sacculitis more frequently than infectious synovitis (Benčina et al., 2001: Khalifa et al., 2013). M. synoviae disseminates very quickly after it is introduced at farm because of its lateral spread both by direct contact and between cages is very quick (Kleven, 2008).

The major pathological finding in M. gallisepticum infection is the air sacculitis while in some birds upper respiratory tract infection may also be present (Hong et al., 2005). Pathogenic mechanisms of Mycoplasmas are controlled by number of pathogenic factors which include ability of pathogen to attach to host cell, type of cell injury and ability to resist host immune response.

\section{IMMUNITY IN MYCOPLASMOSIS}

Immune system of host fails to deal effectively with Mycoplasma specie because of chronic nature of the infection. Mycoplasmas evade the host immune response by antigenic variation of surface proteins. $M$. gallisepticum and $M$. synoviae are transmitted either by vertical method or by direct contact between sick and susceptible birds (Marois et al., 2001). Ability of Mycoplasma to survive within the host cell allows the pathogen to resist immune response of host and antimicrobial therapy (Winner et al., 2000). Age of bird, size of flock and locality of poultry farm are the factors which affect the severity of the disease. Great economic losses occur due to Mycoplasmosis in broiler, breeder and layer birds in terms of condemnation of carcass, reduced eggs production, feed efficiency, hatchability losses and increased cost for the treatment of the infection (Hassan et al., 2012). For treatment and control of Mycoplasmosis early and timely diagnosis is necessary. Isolation of $M$. gallisepticum and $M$. synoviae is not reliable due to least tolerance in adverse environment and the fastidious nature of the organism. In vitro cultivation of Mycoplasma is very difficult, expensive and time consuming. It requires three to four weeks to grow and even after that there 
can be mixed growth or no growth. In the cultures Mycoplasmas are over grown by the fast growing or apathogenic species of Mycoplasma. Serological tests and molecular techniques are reliable methods for diagnosis of the disease Serological tests like serum plate agglutination (SPA) test, ELISA and direct haemagglutination inhibition (HI) tests are used. SPA test is a quick tool for flock screening although it may give false positive results because of cross reactivity of M. gallisepticum and M. synoviae (Kleven, 2008). While conducting serology of $M$. gallisepticum and $M$. synoviae cross reactivity of antigens is common problem (Ehtisham-Ul-Haque et al., 2011). Polymerase chain reaction (PCR) essays are commonly used for rapid detection of the $M$. gallisepticum and $M$. synoviae (Ahmed et al., 2009). Most effective control measure to control Mycoplasmosis is to cull seropositive birds from flock, but this is expensive practice, hence impossible.

Since Mycoplasma lacks cell wall, so cell wall synthesis inhibiting antibodies like penicillin etc are ineffective against the pathogen. Antibiotics that inhibit metabolic processes of microorganisms like macrolides, tetracyclines, fluoroquinoles and others are effective against Mycoplasma (Ley, 2003). Tylosine and gentamycin are effective in higher doses. Tylosine may be toxic to embryos and reduce the hatchability (Nascimento et al., 2005). Tilmicosin has lowest minimum inhibitory concentration (MIC) followed by tylosine for the Mycoplasma species (Hassan et al., 2012)

\section{DIAGNOSIS OF MYCOPLASMOSIS}

For the diagnosis of Mycoplasmosis a number of methods including isolation and identification, serological methods and molecular techniques have been used Cultivation on laboratory media is most reliable method for the confirmatory diagnosis of Mycoplasma (Ley, 2003; Umar et al., 2017).). Due to the limitations of diagnostic tests and the similarities in the disease caused by Mycoplasmas, specific diagnosis is very difficult. It is very important to characterize and identify the Mycoplasma species and strain variability. Brief review of various methods used for diagnosis of Mycoplasma is given below.

\section{Isolation and identification}

Direct isolation and identification of Mycoplasma is not part of routine procedure used for diagnosis of Mycoplasma (Zain and Bradbury, 1996). The main reason for this is the fastidious and slow growing nature of the Mycoplasma species. Mycoplasmas require one to three weeks or even more time for their growth and identification (Umar et al., 2017). Another major problem in isolation of Mycoplasma is the growth of fast growing non-pathogenic Mycoplasma species and growth of other bacteria and fungi (García $\boldsymbol{e t}$ al., 2005). Selective pressures on populations of Mycoplasmas that differ substantially in vivo and in vitro are also an important factor. Pathogenic properties of the strain may be lost during passages in the culture media. Mycoplasma has very small genome and size of genome is 996 kilo base pairs (Papazisi et al., 2003). Mycoplasma has little capacity of biosynthesis and is dependent on host cell for its requirements Mycoplasma is dependent on host for cholesterol, amino acids, fatty acids, vitamins, nucleotides and other nutrients, that is why in vitro growth is very difficult. Mycoplasmas do not have regulatory genes involved in gene expression and cannot respond to the changing environmental conditions in vitro, it makes extremely fastidious to work with this organism (Razin et al., 1998) Mycoplasma once isolated from their host tends to die rapidly if not placed in suitable medium and environment (Zain and Bradbury, 1996). Handling of samples between collection and inoculation is a critical step for isolation of Mycoplasmas. Swabs dipped in Mycoplasma broth and placed at $4^{\circ} \mathrm{C}$ are more viable than dry swabs. Due to these reasons isolation of Mycoplasma is laborious, time consuming, expensive and difficult task. Small size and lack of cell wall make morphological characterization of Mycoplasma very difficult and may no give true picture of in vivo presentation.

In order to overcome deficiencies of Mycoplasma, very complex media are used for in vitro cultivation. Generally growth media for Mycoplasma is composed of protein digest and meat infusion base. The media is also supplemented with horse or swine serum, yeast extract and glucose. To inhibit the growth of bacteria and fungi, bacterial inhibitors and antibiotics are also added (Hong et al., 2005). Thallium acetate and ampicillin are added in media as inhibitors of bacterial growth. Mycoplasmas are resistant to thallium acetate while thallium acetate prevents the growth of gram positive and gram negative bacteria (OIE, 2008) Ampicillin inhibits the growth of bacteria by inhibiting the call wall synthesis and cross linking of peptidoglycans. Ampicillin has no effect on Mycoplasma due to the absence of cell wall. Biochemicals, physiological and morphologica characteristics of Mycoplasmas are affected by composition of media and cultural conditions. Lipid content, nutritional quality and osmotic strength of the medium are very important factors which affect the morphology of Mycoplasma. Mycoplasmas are rapidly mutating organisms and changes may occur in short periods during growth. This ability of diversification plays important role in the pathogenesis of disease caused by Mycoplasma. During the cultivation, pathogenic characteristics of Mycoplasma are lost due to rapidly occurring mutations (Wise et al., 1992). All these attributes of Mycoplasmas should be kept in mind while attempting isolation and cultivation of Mycoplasma. Typical egg fried, small and clear colonies of Mycoplasmas are observed on solid medium as shown in figure 3. Colonies are clear with central whitish raised parts (Kleven, 2008)

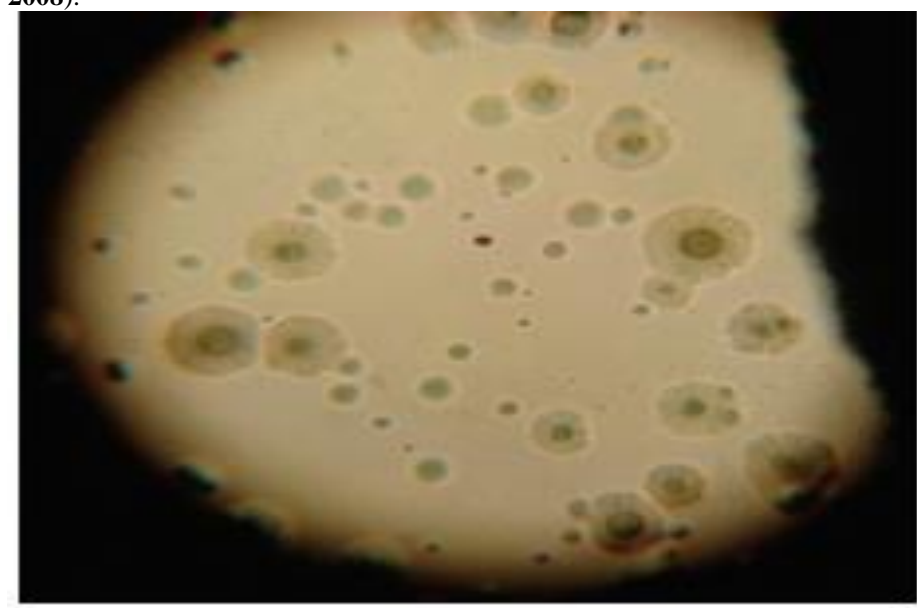

Figure 3 Egg fried colonies of Mycoplasma gallisepticum (Metwally et al., 2014)

\section{Serological techniques}

Many serological tests are routinely used for sero monitoring of flocks against Mycoplasma. Serological tests are easy, give fast detection and require less expertise. These tests include SPA, ELISA, and HI (Kleven, 2008). Although serological tests are quick and fast yet they have their own disadvantages and limitations.

Serological tests are based on detecting antibodies in the serum produced in response to antigens and subsequent detection of these antibodies. To prevent the spread of infection, rapid diagnosis of Mycoplasma is necessary through serological screening. Serological methods do not detect the sub clinical or early infections. As antibodies are produced after minimum one week of infection and it requires three weeks post infection to conduct HI test (Kempf et al., 1993). Another major problem of serological tests is their sensitivity and specificity. Sensitivity and specificity of SPA test are almost same as HI test and ELISA ELISA is not feasible for sero monitoring because it is more time consuming and costly (Higgins and Whithear, 1986). False positive results can give a very high prevalence by SPA test which are because of cross reactivity, use of inactivated vaccine, contaminated sera and age of the flock (Luciano et al., 2011). Major constraint in the use of SPA test for diagnosis is its low specificity (Pourbakhsh et al., 2010). SPA can be used for screening flocks but not for screening individual birds. For proper diagnosis and control, programs based on sero conversion may be inadequate and sero monitoring should be combined with culture and molecular techniques (Luciano et al., 2011).M. gallisepticum is shown to be cross reactive with closely related $M$. imitans that would also lead to aberrance in prevalence of specific Mycoplasma species (Bradbury et al., 1993) This is because both $M$. gallisepticum and $M$. imitans have many similarities including same antigenic and phenotypic properties and same terminal attachment structure (Abdul-Wahab et al., 1996). Flocks showing no clinica signs may be serologically positive if the flock recovered from the infection at younger age (Ley, 2003).

\section{Molecular techniques}

Due to high sensitivity and increasing specificity of the polymerase chain reaction (PCR), it has become valuable tool in the diagnosis of Mycoplasma species. Since PCR is dependent on the target, its specificity is highly flexible. PCR can be species specific or strain specific by targeting unique gene in particular specie or conserved region in a specific strain. For four main avian pathogenic Mycoplasma species PCR essays are developed in 1990s (Raviv and Kleven, 2009). Earlier PCR methods targeted 16S ribosomal DNA (16SrDNA) region but the recent PCR essays target the species specific regions and the surface proteins (Liu et al., 2001; García et al., 2005; Raviv et al., 2007). PCR essays that target $16 \mathrm{~S}$ rDNA region are less specific and may cross react with the other avian Mycoplasmas because 16S rDNA region is highly conserved among phylogenetically related groups (García $\boldsymbol{e t}$ al., 2005). Those PCR essays are less sensitive which target surface proteins because of high levels of intraspecific genetic polymorphism (Raviv et al., 2007). For detection of M. gallisepticum many PCR methods are applied including commercial kits produced by IDEXX Laboratories, Genekam Biotechnology AG etc. PCR essays are developed to target various genes including $16 \mathrm{~S}$ rRNA gene, pvpA, gap A, lipoprotein, mgc2 and 16S-23S intergenic spacer region (Domanska-Blicharzet al., 2008). PCR developed by targeting $16 \mathrm{~S}$ rRNA gene has its own limitations and shortcomings. Although this region is highly conserved but $16 \mathrm{~S}$ rRNA gene of M. gallisepticum and $M$. imitans is very much similar and both organisms are amplified (García $\boldsymbol{e}$ al., 2005). Keeping in mind the above mentioned limitations of PCR essays based 
on 16S rDNA region and 16S rRNA gene, we can say that PCR cannot be solely used to identify M.gallisepticum without possibility of false positive results.

Surface proteins on which PCR essays are based help the Mycoplasma cell to bind to the host cell membrane-receptors. These proteins which mediate the attachment are called cytoadhesins. After the firm attachment of Mycoplasma to host cell, pathogenesis and host cell alterations occur (Goh et al., 1998). One of the important cytoadhesins is encoded by $\mathrm{mgc} 2$ gene (Boguslavsky et al., 2000). For the detection of M. gallisepticum, mgc2-PCR is highly specific and sensitive (García et al,. 2005).

In $M$. gallisepticum, mgc2 gene is fairly conserved and is used for molecular detection of isolates. Essay based on $\mathrm{mgc} 2$ gene is able to differentiate between field strain and the vaccine strain (Lysnyansky et al., 2005). Other cytoadhesins are encoded by gapA gene (Goh $\boldsymbol{e t}$ al., 1998), PvpA gene (Boguslavsky $\boldsymbol{e}$ al ., 2000) and MGA 0319 gene (García et al., 2005). In a study $42.4 \%$ tracheal samples were found positive when Mycoplasma specific primers were used. The reason for the high prevalence by PCR is the detection of DNA from both viable and non viable Mycoplasma (Marois et al., 2001). As compared to culture isolation, PCR is fast, less expensive, effective and more reliable.

\section{CONTROL OF MYCOPLASMOSIS}

The three main components of control program for Mycoplasma include biosecurity, treatment and vaccination. Rapid expansion of poultry industry and high concentration of multi aged birds in the close proximity are the other main reasons for the high incidence of Mycoplasma. Due to these factors and poor biosecurity measures, it is difficult to maintain Mycoplasma free flock (Lysnyansky et al., 2005). Vertical transmission is one of the major reason for ineffective control of Mycoplasma (Papazisi et al., 2002). First step towards the control of Mycoplasma is the acquisition of fertile eggs and poultry birds which are free from Mycoplasma. This can be achieved by antibiotic treatment of fertile eggs and heating the eggs at $46^{\circ} \mathrm{C}$ for $12-14$ hours (Umar et al., 2017).

In the areas where complete eradication is difficult, live vaccines are used as alternative control strategy. There are five commercially available live vaccines for the control of $M$. gallisepticum which include the F strain, K-strain, MS-H strain , Ts-11 and 6/85 strain (Liu et al. 2001; Ferguson-Noel and Williams, 2015). The MG-F strain was described as typical pathogenic and naturally occurring strain. A single dose of MG-F strain vaccine is needed to protect the birds against $M$. gallisepticum (Ley, 2003). The F strain is highly virulent and immunogenic, but is responsible for post vaccination clinical outbreaks. The Ts11 and 6/85 strain originated from Australia and U.S.A respectively (Ferraz and Danelli, 2003). Ts-11 and 6/85 are live vaccines and contain poorly transmitted strains which makes them safer vaccine than MG-F strain vaccine. Ts-11 and 6/85 strain show post vaccination mild respiratory stress but induce lower immunity as compared to MG F strain vaccine (Peebles $\boldsymbol{e t}$ al., 2015; Umar $\boldsymbol{e}$ al., 2017).

Inactivated oil-emulsion bacterins and recombinant vaccines are also used to protect the poultry birds from Mycoplasma. These vaccines are quite successful and have shown minimal resistance against local infections (Jacob et al., 2015) A recombinant fowl pox (rFP-MG) vaccine that possesses and express protective MG antigen is shown to be less effective than live vaccine, but there is no risk of introducing live pathogen (Jacob et al., 2014).

\section{CONCLUSION}

Control of Mycoplasmosis is generally based on the elimination of these organisms from poultry flocks. It is only possible in those flocks where prevalence is low like in grandparent flocks. In layers such approach is not feasible. Medication and vaccination are the parts of control strategy of mycoplasmosis. Poultry industry is expanding fast worldwide. Very close location of the poultry farms, rearing of mixed avian species in close milieus, mixed commercial poultry farming and presence of wild birds in close proximity have made the control of this disease very difficult and almost impossible to maintain Mycoplasma free flocks. Establishment of Mycoplasma free breeding flocks is required for the control of Mycoplasmosis as it is transmitted by vertical method. Before adding to the flock poultry birds should be tested. Breeding stock should be purchased from certified infection free sources. Poultry birds should be hatched and reared in a way to reduce the horizontal transmission by preventing the contact with infected flocks. The poultry equipments and premises should be disinfected and cleaned on regular basis. To eliminate the infection from flock, repeated testing and culling of carrier birds can be helpful. Compounds containing phenols and quaternary ammonium based compounds should be used for effective disinfection. Keeping in mind the economic importance and high incidence of the mycoplasmosis, there is dire need to design the prevalence study to define and quantify the load of avian mycoplasmosis in the region.

\section{REFERENCES}

ABDUL-WAHAB, O.M.S., ROSS, G., BRADBURY, J.M. 1996. Pathogenicity and cytadherence of Mycoplasma imitans in chicken and duck embryo tracheal organ cultures. Infection and Immunity, 64(2), 563-568.
AHMED, A., KHAN, T.A., KANWAL, B., RAZA, Y., AKRAM, M., REHMANI, S.F., KAZMI, S. 2009. Molecular identification of agents causing respiratory infections in chickens from southern region of Pakistan from Octobe 2007 to February 2008. International Journal of Agriculture \& Biology, 11(3), 325-328.

BENČINA, D., DROBNIČ-VALIČ, M., HORVAT, S., NARAT, M., KLEVEN, S.H., DOVČ, P. 2001. Molecular basis of the length variation in the N-terminal part of Mycoplasma synoviae hemagglutinin. FEMS Microbiology Letters, 203(1), 115-123.http://dx.doi.org/ 10.1111/j.1574-6968.2001.tb10829.x

BHANDARI, S., ASNANI, P.J. 1989. Characterization of phospholipase A2 of mycoplasma species. Folia Microbiologica, 34(4), 294-301.

BOGUSLAVSKY, S., MENAKER, D., LYSNYANSKY, I., LIU, T., LEVISOHN, S., ROSENGARTEN, R., GARCÍA, M., YOGEV, D. 2000.Molecular characterization of the Mycoplasma gallisepticum pvpA gene which encodes a putative variable cytadhesin protein. Infection and Immunity, 68(7), 3956-3964

BRADBURY, J.M., ABDUL-WAHAB, O.M., YAVARI, C.A., DUPIELLET, J.P, BOVE, J.M. 1993. Mycoplasma imitans sp. nov. is related to Mycoplasma gallisepticum and found in birds. International journal of systematic bacteriology, 43(4), 721-728. http://dx.doi.org/ 10.1099/00207713-43-4-721

BRADBURY, J.M., MORROW, C. 2008. Avian mycoplasmas. Poultry Diseases, p. 220-234.

DOMANSKA-BLICHARZ, K., TOMCZYK, G., MINTA, Z. 2008. Comparison of different molecular methods for detection of Mycoplasma gallisepticum. Bulletin of Veterinary Institue in Pulawy, 52, 529-532.

EHTISHAM-UL-HAQUE, S., RAHMAN, S.U., SIDDIQUE, M., QURESHI, A.S. 2011. Involvement of Mycoplasma synoviae in respiratory distress cases of broilers. Pakistan Veterinary Journal, 31(2), 117-119.

EVANS, J.D., LEIGH, S.A., BRANTON, S.L., COLLIER, S.D., PHARR, G.T., BEARSON, S.M.D. 2005. Mycoplasma gallisepticum: Current and developing means to control the avian pathogen. the Journal of Applied Poultry research, 14(4), 757-763. http://dx.doi.org/ 10.1093/japr/14.4.757

FAN, H.H., KLEVEN, S.H., JACKWOOD, M.W. 2011. Application of polymerase chain reaction with arbitrary primers to strain identification of Mycoplasma gallisepticum. Avian diseases, 39(4), 729-735.

FERGUSON-NOEL, N.M., WILLIAMS, S.M. 2015. The efficacy of Mycoplasma gallisepticum K-strain live vaccines in broiler and layer chickens. Avian Pathology, 44(2), 75-80. http://dx.doi.org/10.1080/03079457.2015.1005054

FERRAZ, P.N., DANELLI, M.D.G.M. 2003. Phenotypic and antigenic variation of Mycoplasma Gallisepticum vaccine strains. Brazilian Journal of Microbiology,34(3), 238-241. http://dx.doi.org/10.1590/S151783822003000300011

FORRESTER, C.A., BRADBURY, J.M., DARE, C.M., DOMANGUE, R.J., WINDSOR, H., TASKER, J.B., MOCKETT, A.P.A. 2011. Mycoplasma gallisepticum in pheasants and the efficacy of tylvalosin to treat the disease. Avian Pathology, 40(6),

http://dx.doi.org/10.1080/03079457.2011.618822

GARCÍA, M., IKUTA, N., LEVISOHN, S., KLEVEN, S.H. 2005. Evaluation and comparison of various PCR methods for detection of Mycoplasma gallisepticum infection in chickens. Avian diseases, 49(1), 125-32. http://dx.doi.org/10.1637/7261-0812204R1

GOH, M.S., GORTON, T.S., FORSYTH, M.H., TROY, K.E., GEARY, S.J. 1998. Molecular and biochemical analysis of a $105 \mathrm{kDa}$ Mycoplasma gallisepticum cytadhesin (GapA). Microbiology, 144, 2971-2978. http://dx.doi.org/10.1099/00221287-144-11-2971

HASSAN, W.H., SHAMA, U.H., ZAIN, A.Z. 2012. Bacteriological and molecular studies on Mycoplasma infection in turkey from Egypt. Beni-Suef University Journal of Applied Sciences, 1(2), 69-79.

HIGGINS, P.A., WHITHEAR, K.G. 1986. Detection and differentiation of Mycoplasma gallisepticum and M. synoviae antibodies in chicken serum using enzyme-linked immunosorbent assay. Avian diseases, 30(1), 160-168. http://dx.doi.org/10.2307/1590628

HONG, Y., GARCÍA, M., LEVISOHN, S., SAVELKOUL, P., LEITING, V., LYSNYANSKY, I., LEY, D.H., KLEVEN, S.H. 2005. Differentiation of Mycoplasma gallisepticum strains using amplified fragment length polymorphism and other DNA-based typing methods Avian diseases, 49(1), 4349. http://dx.doi.org/10.1637/7254-080504R

JACOB, R., BRANTON, S.L., EVANS, J.D., LEIGH, S.A., PEEBLES, E.D. 2014. Effects of live and killed vaccines against Mycoplasma gallisepticum on the performance characteristics of commercial layer chickens. Poultry Science, 93(6), 1403-1409. http://dx.doi.org/10.3382/ps.2013-03748.

JACOB, R., BRANTON, S.L., EVANS, J.D., LEIGH, S.A., PEEBLES, E.D 2015. Effects of different vaccine combinations against Mycoplasma gallisepticum on the internal egg and eggshell characteristics of commercial layer chickens. Poultry Science, 94(5), 912-917. doi: 10.3382/ps/pev060.

KEMPF, I., BLANCHARD, A., GESBERT, F., GUITTET, M., BENNEJEAN, G. 1993. The polymerase chain reaction for Mycoplasma gallisepticum detection. Avian Pathology, 22(4), 739-750. http://dx.doi.org/10.1080/03079459308418961. 
KHALIFA, K.A., ABDELRAHIM, E.S., BADWI, M., MOHAMED, A.M 2013. Isolation and molecular characterisation of Mycoplasma gallisepticum and Mycoplasma synoviae in chickens in Sudan. Journal of Veterinary Medicine, 2013, 1-4. http://dx.doi.org/10.1155/2013/208026

KLEVEN, S.H. 2008. Control of avian mycoplasma infections in commercial poultry. Avian diseases, 52(3), 367-374. http://dx.doi.org/ 10.1637/8323-041808 Review.1

LIU, T., GARCÍA, M., LEVISOHN, S., YOGEV, D., KLEVEN, S. H. 2001 Molecular variability of the adhesin-encoding gene pvpA among Mycoplasma gallisepticum strains and its application in diagnosis. Journal of Clinical Microbiology, 39(5), 1882-1888. http://dx.doi.org/10.1128/JCM.39.5.18821888.2001

LUCIANO, R.L., CARDOSO, L.S.P., STOPPA, G.F.Z., KANASHIRO, M.I., DE CASTRO, G.M., TESSARI, E.N.C. 2011. Comparative Study of Serologica Tests for Mycoplasma synoviae Diagnosis in Commercial Poultry Breeders. Veterinary medicine international, 2011, 3043 3049. http://dx.doi.org/10.4061/2011/304349

LYSNYANSKY, I., GARCIA, M., LEVISOHN, S. 2005. Use of mgc2 polymerase chain reaction-restriction fragment length polymorphism for rapid differentiation between field isolates and vaccine strains of Mycoplasma gallisepticum in Israel. Avian diseases, 49(2), 238-45. http://dx.doi.org/10.1637/7285-10020R

Ley, D.L. 2008. Mycoplasmosis: Mycoplasma gallisepticuminfection. In Disease of Poultry, 11th Edition, pp. 807-834. Edited by Y.M. Saif, A.M. Fadly, J.R., Glisson, L.R., McDougald, L.K., Nolan, and Swayne, D. E. Blackwell Publishing, Ames, IA.

LEY, D.H. 2003. Mycoplasma gallisepticum infection. In: Saif, Y.M., Barnes, H J., Glisson J. R.,, Fadly, A. M., McDougald, L. R. and Swayne, D. E. (Eds.), Diseases of Poultry. Iowa State University Press, Ames, Iowa, USA: 722-744. MAROIS, C., DUFOUR-GESBERT, F. \& KEMPF, I.(2001). Molecular differentiation of Mycoplasma gallisepticum and Mycoplasma imitans strains by pulsed-field gel electrophoresis and random amplified polymorphic DNA Journal of Veterinary Medicine, 48(9), 695-703.

METWALLY, M. A., AYMEN, S. Y., TAME,R M. E., HAYAM, M. H MAGDY, A. A. 2014. Detection, Characterization, and Molecular Typing of Human Mycoplasma spp. from Major Hospitals in Cairo, Egypt. The Scientific World Journal, 2014, 1-6. http://dx.doi.org/10.1155/2014/549858

MUCH, P., WINNER, F., STIPKOVITS, L., ROSENGARTEN, R., CITTI, C. 2002. Mycoplasma gallisepticum: Influence of cell invasiveness on the outcome of experimental infection in chickens. FEMS Immunology and Medical Microbiology, 34(3), 181-186. $\quad$ http://dx.doi.org/10.1111/j.1574695X.2002.tb00622.x

MUKHTAR, M., AWAIS, M. M., ANWAR, M. I., HUSSAIN, Z., BHATTI, N. ALI, S. 2012. Seroprevalence of Mycoplasma gallisepticum Among Commercia Layers in Faisalabad, Pakistan. Journal of Basic \& Applied Sciences, 8, 183-186. NASCIMENTO, E.R., NASCIMENTO, M., SANTOS, M.W., DIAS, P.G., RESENDE, O. and SILVA, C.F. 2005. Eradication of Mycoplasma gallisepticum and M. synoviae from a chicken flock by antimicrobial injections in eggs and chicks. Acta Scientiae Veterinariae, 33(2), 119-124.

NICHOLAS, R.A.J., AYLING, R.D. 2003. Mycoplasma bovis: disease diagnosis, and control. Research in Veterinary Science, 74(2), 105-112.

NUNOYA, T., YAGIHASHI, T., TAJIMA, M., NAGASAWA, Y. 1995 Occurrence of keratoconjunctivitis apparently caused by Mycoplasma gallisepticum in layer chickens. Veterinary pathology, 32(1), 11-18. http://dx.doi.org/10.1177/030098589503200102

OIE, 2008. Avian mycoplasmosis (Mycoplasma gallisepticum, M. synoviae) Viewed 15 May 2012, http://www.oie.int/fileadmin/Home/eng/Health_standards/ tahm

PEEBLES, E.D., JACOB, R., BRANTON, S.L., EVANS, J.D., LEIGH, S.A., GERARD, P.D. (2015). Effects of different vaccine combinations agains Mycoplasma gallisepticum on blood characteristics in commercial layer chickens. Poultry http://dx.doi.org/10.3382/ps/pev269

POURBAKHSH, S.A., SHOKRI, G.R., BANAN, M., HAMNIA, F., ASHTARI, A. 2010. Detection of Mycoplasma synoviae infection in broiler breeder farms of Tehran province using PCR and culture methods. Archives of Razi Institute, 65(2), 75-81. http://dx.doi.org/10.22092/ARI.2010.103853

PAPAZISI, L., SILBART, L. K., FRASCA, S., ROOD, D., LIAO, X., GLADD, M., JAVED, M. A., GEARY, S. J. 2002. A modified live Mycoplasma gallisepticum vaccine to protect chickens from respiratory disease. Vaccine, 20(31): 3709-3719. http://dx.doi.org/10.1016/S0264-410X(02)00372-9

Papazisi, L., Gorton, T. S., Kutish, G., Markham, P.F., Browning, G. F., Nguyen, D. K., Swartzell, S., Madan, A., Mahairas, G., Geary, S. J. 2003. The complete genome sequence of the avian pathogen Mycoplasma gallisepticum strain R(low). Microbiology, 149(9), 2307-2316 http://dx.doi.org/10.1099/mic.0.26427-0

RAVIV, Z., CALLISON, S., FERGUSON-NOEL, N., LAIBINIS, V., WOOTEN, R., KLEVEN, S. H. 2007. The Mycoplasma gallisepticum 16S-23S rRNA intergenic spacer region sequence as a novel tool for epizootiological studies. Avian diseases, 51(2), 555-60. http://dx.doi.org/10.1637/00052086(2007)51[555:TMGSRI]2.0.CO;2

RAVIV, Z., KLEVEN, S.H. 2009. The development of diagnostic real-time TaqMan PCRs for the four pathogenic avian mycoplasmas. Avian diseases, 53(1), 103-107. http://dx.doi.org/10.1637/8469-091508-Reg.1

RAZIN, S., YOGEV, D., NAOT, Y. 1998. Molecular biology and pathogenicity of mycoplasmas. Microbiology and molecular biology reviews, 62(4), 1094 1156.

RAZIN, S. 2006. The genus Mycoplasma and related genera (Class Mollicutes) In The Prokaryotes: Bacteria: Firmicutes, Cyanobacteria, 11th Edition, 879. Edited by Dworkin, M. and Stanley, F. Springer, New York.

SAIF, Y. M., BARNES, H. J., GLISSON, J., FADLY, A. M., MCDOUGALD, R., SWAYNE, D. E. 2003. Diseases of Poultry; 11th ed. Iowa State Press, Ames, USA: 722-43.

SIDDIQUE, A.B., SAJJAD, R., HUSSAIN, I., MUHAMMAD, G. 2012. Frequency distribution of opportunistic avian pathogens in respiratory distress cases of poultry. Pakistan Veterinary Journal, 32(3), 386-389.

SIMECKA, J. W., DAVIS, J. K., DAVIDSON, M. K., ROSS, S.E., STÄDTLANDER, C.T. K.H., CASSELL, G.H. 1992. Mycoplasma diseases of animals. In Mycoplasmas: Molecular biology and pathogenesis, 391-415.

SUN, S., XIN, L., JUNMEI, L., ZHONGQIANG, T., FENG, C., YONGCHANG, C., JIANPING, Q., TINGRONG, L. 2017. Phylogenetic and pathogenic analysis of Mycoplasma Synoviae isolated from native chicken breeds in China. Poultry Science, 96(7), 2057-2063. http://dx.doi.org//10.3382/ps/pew484

UMAR, S., MUNIR, M.T., REHMAN, Z., SUBHAN, S., AZAM, T., SHAH, M.A.A. 2017. Mycoplasmosis in poultry: update on diagnosis and preventive measures. World's Poultry Science Journal, 73(1), 1-12. http://dx.doi.org/10.1017/S0043933916000830.

WINNER, F., ROSENGARTEN, R., CITTI, C. 2000. In vitro cell invasion of Mycoplasma gallisepticum. Infection and immunity, 68(7), 4238-44.

WISE, K.S.D., YOGEV, A \& ROSENGARTEN, R. 1992. Antigenic variation. In Mycoplasmas: Molecular Biology and Pathogenesis, 473-489. Edited by Maniloff, J., McElhaney, R. N., Finch, L. R. and Baseman, J. B. American Society for Microbiology, Washington, DC.

XU, J., TENG, D., JIANG, F., ZHANG, Y., EL-ASHRAM, S.A., WANG, H SUN, Z., HE, J., SHEN, J., WU, W., LI, J. 2015. Mycoplasma gallisepticum MGA-0676 is a membrane-associated cytotoxic nuclease with a staphylococcal nuclease region essential for nuclear translocation and apoptosis induction in chicken cells. Applied Microbiology and Biotechnology, 99(4), 1859-1871. http://dx.doi.org/10.1007/s00253-014-6185-6.

ZAIN, Z.M., BRADBURY, J. M. 1996. Optimising the conditions for isolation of Mycoplasma gallisepticum collected on applicator swabs. Veterinary Microbiology, 49(1), 45-57. 